\title{
PENERAPAN PENDEKATAN PROBLEM SOLVING UNTUK MENINGKATKAN KEMAMPUAN PEMECAHAN MASALAH MATEMATIS SISWA BERDASARKAN LEVEL SISWA
}

\author{
Husna \\ Universitas Jabal Ghafur Pidie-Aceh \\ Email: husna.math11@gmail.com \\ Fona Fitry Burais \\ Universitas Jabal Ghafur Pidie-Aceh \\ Email: fonaburaisfitry.math11@gmail.com
}

\begin{abstract}
Abstrak
Problem-solving is a process or thinking activity to solve a problem. Mathematical problem-solving skillis needed for students both in the process of understanding mathematics itself and in everyday life. The problem solving can beachieved by implementingthe learning using a problem-solving approachwhich trains students to deal with various problems including individuals and group problemsto be addressed individually or together. This learning is oriented towards the investigation and discovery which is solving the problems. It is the basis for students to solve problems critically, systematically, logically, and creatively as well as the ability to collaborateeffectively and to present fundamental knowledge which in turn can improvethe solving skill. This study aimed to examine whether the improvement of mathematical problem-solving skillof students learned with the problem-solving approach wasbetter than students taught using the conventional learning. The improvement was examined based on the students' levels. This study applied a pre-test and post-test control group design. The population of the study was Year 7 students of one of the junior high schools in Pidie, Indonesia, consisting of seven classes in 2017/2018.Two classes, a control, and an experimental class were selected as the sample through purposive sampling technique. The instrument used to obtain the data is the mathematical problem-solving skill test.The data was then analyzed by employing a two-way ANOVA test using SPSS. The results of the study showed that the improvement of mathematical problem-solving skill of the students learning with the problem-solving approach is better than the students experiencing the conventional learning, reviewed based on student levels. There is no interaction between the learning models and student levels on mathematical problem-solving skills. The resultsare expected to be used as a reference for mathematics teachers to apply the problem-solving approach in the learning process to improve mathematical problem-solving skills.
\end{abstract}


Al-Ishlah: Jurnal Pendidikan - ISSN: 2087-949o (p); 2597-940X (e)

Vol. 11, No. 1 (2019)

Pemecahan masalah merupakan proses atau aktivitas berpikir untuk menyelesaikan persoalan yang sedang dihadapi. Kemampuan pemecahan masalah matematis sangat dibutuhkan bagi siswa, baik dalam proses memahami matematika maupun dalam kehidupan sehari-hari. Pemecahan masalah dapat diwujudkan dengan pembelajaran pendekatan problem solving, yaitu pembelajaran dengan jalan melatih peserta didik dalam menghadapi berbagai masalah, baik itu perorangan maupun kelompok, untuk dipecahkan sendiri atau bersama-sama. Pembelajaran ini berorientasi investigasi dan penemuan yang pada dasarnya memecahan masalah. Pembelajaran tersebut sebagai dasar siswa untuk menyelesaikan masalah secara kritis, sistematis, logis, kreatif, dan mampu bekerja sama secara efektif serta mampu mempresentasikan ilmu yang mendasar, sehingga hal ini dapat meningkatkan kemampuan pemecahan masalah matematis. Penelitian ini bertujuan untuk mengkaji peningkatan kemampuan pemecahan masalah matematis siswa yang memperoleh pembelajaran dengan pendekatan problem solving lebih baik daripada siswa yang memperoleh pembelajaran konvensional ditinjau berdasarkan level siswa. Penelitian ini menggunakan desain pretest posttest control group design. Populasi dalam penelitian ini adalah seluruh siswa kelas VII SMP Negeri Simpang Tiga, Pidie, yang terdiri atas 7 kelas pada tahun pelajaran 2017/2018. Untuk sampel diambil dua kelas, yaitu kelas VIIe sebagai kelas kontrol dan kelas VII $f$ sebagai kelas eksperimen melalui teknik purposive sampling. Instrumen digunakan untuk memperoleh data penelitian berupa tes kemampuan pemecahan masalah matematis. Uji statistik yang digunakan untuk menganalisis data peningkatan kemampuan pemecahan masalah matematis adalah uji anava dua jalur diolah dengan menggunakan bantuan SPSS. Hasil penelitian menunjukkan bahwa peningkatan kemampuan pemecahan masalah matematis siswa yang memperoleh pendekatan problem solving lebih baik daripada siswa yang memperoleh pembelajaran konvensional, ditinjau dari level siswa. Hasil ini diharapkan dapat menjadi acuan bagi guru matematika untuk menerapkan pendekatan problem solving dalam proses pembelajaran guna meningkatkan kemampuan pemecahan masalah matematis.

Kata Kunci: Pendekatan Problem Solving, Pemecahan Masalah Matematika, Level Siswa

\section{PENDAHULUAN}

Pembelajaran matematika di sekolah menengah pertama dalam standar isi (BSNP, 2006) bertujuan agar siswa memiliki kemampuan: (1) memahami konsep matematika, menjelaskan keterkaitan antar konsep, dan mengaplikasikan konsep atau algoritma secara luwes, akurat, efisien, dan tepat dalam pemecahan masalah; (2) menggunakan penalaran pada pola dan sifat, melakukan manipulasi matematika dalam membuat generalisasi, menyusun bukti, atau menjelaskan gagasan dan pernyataan matematika; (3) memecahkan masalah yang meliputi 
Al-Ishlah: Jurnal Pendidikan - ISSN: 2087-949o (p); 2597-940X (e)

Vol. 11, No. 1 (2019)

kemampuan memahami masalah, merancang model matematika, menyelesaikan model, dan menafsirkan solusi yang diperoleh; (4) mengomunikasikan gagasan dengan simbol, tabel, diagram, atau media lain untuk memperjelas keadaan atau masalah; (5) memiliki sikap menghargai kegunaan matematika dalam kehidupan, yaitu memiliki rasa ingin tahu, perhatian, dan minat dalam mempelajari matematika serta sikap ulet dan percaya diri dalam pemecahan masalah. NCTM (2000) menyebutkan bahwa tujuan pembelajaran matematika yaitu mengembangkan kemampuan (1) penalaran matematis, (2) komunikasi matematis, (3) pemecahan masalah matematis, (4) koneksi matematis, dan (5) representasi matematis.

Tujuan pembelajaran tersebut menunjukkan bahwa pemecahan masalah matematis merupakan salah satu aspek penting yang harus dikembangkan dalam proses pembelajaran. Selain itu, NCTM (2000) juga mengungkapkan tujuan pengajaran pemecahan masalah secara umum adalah untuk (1) membangun pengetahuan matematika baru; (2) memecahkan masalah yang muncul dalam matematika dan konteks-konteks lainnya; (3) menerapkan dan menyesuaikan bermacam-macam strategi yang sesuai untuk memecahkan permasalahan dan (4) memantau dan merefleksikan proses dari pemecahan masalah matematika.

Kemampuan pemecahan masalah matematis sangat dibutuhkan bagi siswa, baik dalam proses memahami matematika maupun dalam kehidupan sehari-hari. Kemampuan memecahkan masalah sangat berguna dalam menyelesaikan permasalahan-permasalahan yang terjadi pada diri sendiri, lingkungan, dan masyarakat sekitar. Akan tetapi, kenyataan yang terjadi di lapangan justru sebaliknya, kemampuan pemecahan masalah siswa Indonesia masih belum sesuai dengan yang diharapkan. Hal ini terlihat dari pencapaian prestasi belajar siswa Indonesia di bidang matematika menurun. Hasil studi Trends in International Mathematics and Science Study (TIMSS) tahun 2011 menunjukkan pencapaian prestasi belajar siswa Indonesia di bidang matematika menurun, disebabkan siswa Indonesia masih dominan pada kemampuan menghafal dalam pembelajaran matematika. Sehingga, Indonesia berada di urutan ke-38 dari 42 negara. Hasil skor Indonesia tahun 2011 in ilebih rendah dari penilaian tahun 2007. Dalam hal ini, aspek yang dinilai adalah pengetahuan, penerapan, serta penalaran soal-soal nonrutin yang melibatkan pemecahan masalah (Wardhani, 2011).

Kenyataan tersebut menunjukkan bahwa kemampuan berpikir tingkat tinggi dalam matematika, seperti pemecahan masalah matematis siswa, masih jauh dari yang diharapkan dalam kurikulum. Adapun siswa yang ditinjau berasal dari sekolah SMPN Simpang Tiga yang dikelompokkan berdasarkan level siswa, yaitu siswa yang berkemampuan tinggi, sedang, dan rendah. Rendahnya hasil belajar siswa tersebut sekaligus menjadi gambaran mutu pendidikan matematika 
Al-Ishlah: Jurnal Pendidikan - ISSN: 2087-949o (p); 2597-940X (e)

Vol. 11, No. 1 (2019)

di Indonesia yang kurang baik. Hal ini tidak dapat dianggap sepele sehingga perlu mendapatkan perhatian yang lebih serius dari semua kalangan, terutama guru matematika. Banyak faktor yang menyebabkan rendahnya kemampuan pemecahan masalah matematis siswa dalam proses pembelajaran. Salah satunya adalah pendekatan pembelajaran yang masih terlalu didominasi peran guru. Oleh karena itu, diperlukan suatu pendekatan pembelajaran yang tepat sehingga dapat mengubah proses pembelajaran dari yang didominasi guru menjadi didominasi siswa. Salah satu inovasi yang diduga dapat mewujudkan proses pembelajaran seperti itu adalah pembelajaran matematika dengan pendekatan problem solving

Pembelajaran dengan menggunakan pendekatan problem solving adalah pembelajaran dengan jalan melatih peserta didik dalam menghadapi berbagai masalah, baik itu perorangan maupun kelompok, untuk dipecahkan sendiri dan/tau bersama-sama. Pembelajaran problem solving berorientasi investigasi dan penemuan yang pada dasarnya adalah pemecahan masalah. Pembelajaran tersebut sebagai dasar bagi siswa untuk menyelesaikan masalah secara kritis, sistematis, logis, kreatif, dan mampubekerja sama secara efektif serta mampu mempresentasikan ilmu yang mendasar, sehingga hal ini dapat meningkatkan kemampuan pemecahan masalah matematis.

Problem solving adalah rangkaian aktivitas pembelajaran yang berfokus pada proses penyelesaian masalah yang dihadapi siswa secara ilmiah untuk meningkatkan penguasaan terhadap materi, melatih keterampilan pemecahan masalah, dan menunjukkan hubungan antara teori dan kenyataan. Oleh karena itu, secara umum dapat dikatakan bahwa pendekatan problem solving diduga dapat meningkatkan kemampuan pemecahan masalah matematis siswa.

\section{Pendekatan Problem Solving}

Bransford dan Stein (1993) mengungkapkan bahwa pendekatan problem solving sebagai suatu strategi pembelajaran yang digunakan untuk meningkatkan kemampuan berpikir dan menyelesaikan masalah. Strategi pembelajaran ini didasarkan pada penelitian dan hasil karya dari ahli-ahli sebelumnya dalam penyelesaian masalah seperti Max Wertheimer, George Polya, Alan Newell, dan Herbert Simon. Terdapat 5 tahap sebagai strategi pembelajaran melalui pendekatan problem solving ini, yaitu sebagai berikut.

a. Identify the problem (mengidentifikasi masalah)

Mengidentifikasi masalah merupakan tahap awal dari strategi ini. Kemampuan untuk mengidentifikasi (identify) keberadaan masalah adalah satu karateristik penting untuk menunjang keberhasilan pemecahan masalah dan menjadikannya sebagai kesempatan (opportunities) untuk melakukan sesuatu yang kreatif. Guru membantu siswa dalam memahami aspek-aspek permasalahan, seperti membantu untuk mengembangkan/menganalisis 
Al-Ishlah: Jurnal Pendidikan - ISSN: 2087-949o (p); 2597-940X (e)

Vol. 11, No. 1 (2019)

permasalahan, mengajukan pertanyaan, mengkaji hubungan antardata, memetakan masalah, mengembangkan berbagai hipotesis.

b. Define the problem (mendefinisikan masalah dan menetapkan tujuan)

Dalam tahap ini, kegiatan guru meliputi membantu dan membimbing siswa melihat hal/data/variable, baik yang sudah diketahui maupun yang belum diketahui, untuk mencari dan menyaring berbagai informasi yang ada, kemudian merumuskan permasalahan. Sebuah masalah yang ada bergantung pada cara menentukan tujuan yang mempunyai efek penting terhadap tipe jawaban yang akan dicoba. Perbedaan dalam penentuan tujuan dapat menjadi penyebab yang sangat kuat terhadap kemampuan seseorang untuk berpikir dan menyelesaikan masalah (Bransford, 1993). Tujuan yang berbeda membuat orang mengeksplorasi strategi yang berbeda untuk menyelesaikan masalah.

c. Explore solution (mencari solusi)

Langkah ketiga adalah mengeksplorasi (explore) solusi yang memungkinkan dan mengevaluasi kemungkinan strategi tersebut sesuai dengan tujuan yang telah ditetapkan. Dalam tahap ini, kegiatan guru adalah membantu dan membimbing siswa mencari berbagai alternatif pemecahan masalah, melakukan brainstorming, melihat alternatif pemecahan masalah dari berbagai sudut pandang, dan akhirnya memilih satu alternatif pemecahan masalah yang tepat.

d. Act on the strategy (melaksanakan strategi)

Melakukan langkah-langkah pemecahan masalah sesuai dengan alternatif yang telah dipilih. Dalam tahap ini, siswa dibimbing secara tahap demi tahap dalam melakukan pemecahan masalah.

e. Look back and evaluate the effect (mengkaji kembali dan mengevaluasi pengaruh)

Langkah kelima adalah melihat kembali akibat yang nyata dari strategi yang digunakan dan mengevaluasi atau mempelajari hal yang telah dialami. Melihat dan mengevaluasi perlu dilakukan, karena setelah mendapatkan hasil, banyak yang lupa untuk melihat kembali dan belajar dari penyelesaian masalah yang telah dilakukan. Dalam tahap ini, kegiatan guru adalah membimbing siswa melihat/mengoreksi kembali cara-cara pemecahan masalah yang telah dilakukan sudah benar, sempurna, atau lengkap. Siswa juga dibimbing untuk melihat pengaruh strategi yang digunakan dalam pemecahan masalah.

\section{Pemecahan Masalah Matematis}

Pemecahan masalah adalah proses melibatkan suatu tugas yang metode pemecahannya belum diketahui. Untuk mengetahui penyelesaiannya, siswa hendaknya memetakan pengetahuan terlebih dahulu. Melalui proses ini, mereka sering mengembangkan pengetahuan baru tentang matematika, sehingga pemecahan masalah merupakan bagian yang tidak terpisahkan dalam semua 
Al-Ishlah: Jurnal Pendidikan - ISSN: 2087-949o (p); 2597-940X (e)

Vol. 11, No. 1 (2019)

bagian pembelajaran matematika dan juga tidak harus diajarkan secara terisolasi dari pembelajaran matematika (Turmudi, 2008). Menurut Suherman, dkk. (2003), pemecahan masalah merupakan bagian dari kurikulum matematika yang sangat penting karena dalam proses pembelajaran maupun penyelesaian, siswa dimungkinkan memperoleh pengalaman menggunakan pengetahuan serta keterampilan yang sudah dimiliki untuk diterapkan pada pemecahan masalah yang bersifat tidak rutin. Jacob (2013) mengemukakan bahwa pemecahan masalah sering dilihat sebagai sejumlah keterampilan yang diajarkan pada kurikulum sekolah. Menurut pandangannya, pemecahan masalah tidak selalu dianggap sebagai keterampilan kesatuan, tetapi ada keterampilan arah yang jelas dalam penyelesaian masalah.

Branca dalam Krulik dan Reys (1980) mengemukakan bahwa pemecahan masalah memiliki tiga interpretasi yaitu pemecahan masalah (1) sebagai suatu tujuan utama; (2) sebagai sebuah proses; dan (3) sebagai keterampilan dasar. Ketiga hal itu mempunyai implikasi dalam pembelajaran matematika. Pertama, jika pemecahan masalah merupakan suatu tujuan, ia terlepas dari masalah atau prosedur yang spesifik, juga terlepas dari materi matematika. Hal yang terpenting adalah cara memecahkan masalah sampai berhasil. Dalam hal ini, pemecahan masalah sebagai alasan utama untuk belajar matematika. Kedua, jika pemecahan masalah dipandang sebagai suatu proses, penekanannya bukan semata-mata pada hasil, melainkan pada metode, prosedur, strategi, dan langkah-langkah tersebut dikembangkan melalui penalaran dan komunikasi untuk memecahkan masalah. Ketiga, pemecahan masalah sebagai keterampilan dasar atau kecakapan hidup (life skill), karena setiap manusia harus mampu memecahkan masalahnya sendiri. Jadi, pemecahan masalah merupakan keterampilan dasar yang harus dimiliki setiap siswa. Tujuan kurikulum 2006 dituliskan bahwa pemecahkan masalah meliputi kemampuan memahami masalah, merancang model matematika, menyelesaikan model, dan menafsirkan solusi yang diperoleh. Tujuan ini sama halnya dengan yang diungkapkan Polya dalam Suherman (2003) bahwa solusi untuk pemecahan masalah memuat empat langkah penyelesaian, yaitu memahami masalah, merencanakan penyelesaian, menyelesaikan masalah sesuai rencana, dan melakukan pengecekan kembali terhadap semua langkah yang telah dikerjakan.

\section{Indikator Kemampuan Pemecahan Masalah Matematis}

Untuk mengukur kemampuan pemecahan masalah matematis diperlukan beberapa indikator. Adapun indikator tersebut, menurut Sumarmo (2012), adalah sebagai berikut: (1) mengidentifikasi unsur yang diketahui, ditanyakan, dan kecukupan unsur; (2) membuat model matematika; (3) menerapkan strategi menyelesaikan masalah di dalam/di luar matematika; 
Al-Ishlah: Jurnal Pendidikan - ISSN: 2087-949o (p); 2597-940X (e)

Vol. 11, No. 1 (2019)

menjelaskan/menginterpretasikan hasil; (5) menyelesaikan model matematika dan masalah nyata; dan (6) menggunakan matematika secara bermakna.

George Polya menjelaskan dalam How to Solve It secara garis besar bahwa terdapat empat langkah utama dalam pemecahan masalah, yaitu: understanding the problem, devising a plan, carrying out the plan, dan looking back (Motter, 2010). Secara rinci, keempat langkah itu diuraikan sebagai berikut.

1. Memahami masalah

Dalam proses pemecahan masalah, langkah awal yang dilakukan adalah memahami masalah. Artinya, terdapat hubungan antara kemampuan pemahaman dan pemecahan masalah. Kemampuan pemahaman yang baik akan mendukung proses pemecahan masalah yang akhirnya akan mendukung berkembangnya kemampuan pemecahan masalah. Dengan memahami masalah, dapat ditentukan langkah selanjutnya yang digunakan dalam penyelesaian masalah. Tinggi rendahnya kemampuan pemahaman siswa terhadap masalah maupun hubungan antarkonsep, akan mempengaruhi kemampuan siswa dalam pemecahan masalah.

2. Menyusun rencana pemecahan masalah

Salah satu strategi yang dapat digunakan dalam proses pemecahan masalah yaitu mencari pola dari masalah yang diberikan. Strategi mencari pola diawali adanya proses pengenalan dan observasi terhadap sifat-sifat atau karakteristik yang terdapat pada sekumpulan bilangan, simbol, atau gambar. Observasi tersebut akan membantu siswa dalam menemukan keteraturan dan hubungan antarbilangan atau gambar tersebut. Melalui keteraturan itu dapat dicari pola dari masalah yang diberikan. Jika pola masalah sudah dapat ditentukan, akan mempermudah dalam menyelesaikan masalah ke tahap selanjutnya. Proses mencari pola ini tidak berlangsung begitu saja, melainkan melalui pengalaman dan latihan yang selalu dilakukan.

3. Melaksanakan rencana penyelesaian masalah

Melaksanakan rencana penyelesaian masalah dapat dilakukan dalam beberapa aktivitas berikut.

a. Melaksanakan strategi sesuai dengan yang direncanakan pada tahap sebelumnya.

b. Melakukan pemeriksaan pada setiap langkah yang dikerjakan. Langkah ini dapat berupa pemeriksaan secara intuitif atau juga berupa pembuktian secara formal.

c. Mengupayakan agar pekerjaan dilakukan secara akurat.

4. Pemeriksaan kembali

Proses pemeriksaan kembali untuk menyelesaikan masalah dapat dilakukan dalam beberapa kegiatan berikut. 
Al-Ishlah: Jurnal Pendidikan - ISSN: 2087-9490 (p); 2597-940X (e)

Vol. 11, No. 1 (2019)

a. Periksa hasilnya pada masalah asal (dalam kasus tertentu, hal seperti ini perlu pembuktian).

b. Interpretasikan solusi dalam konteks masalah asal (apakah solusi yang dihasilkan masuk akal?).

c. Temukan kemungkinan cara lain untuk menyelesaikan masalah tersebut.

d. Jika memungkinkan, tentukan masalah lain yang berkaitan atau masalah lain yang lebih umum dengan strategi yang digunakan.

Berdasarkan uraian di atas, dalam penelitian ini, kemampuan pemecahan masalah yang akan diukur melalui kemampuan siswa dalam menyelesaikan suatu masalah menggunakan langkah-langkah pemecahan masalah menurut Polya, yaitu: (1) memahami masalah, (2) menyusun rencana pemecahan masalah, (3) melaksanakan rencana penyelesaikan masalah, dan (4) melakukan pengecekan kembali. Dengan alasan bahwa langkah-langkah yang digunakan Polya sering digunakan dalam pemecahan masalah.

Beberapa penelitian yang relevan, antara lain penelitian Suhendri (2013), menemukan bahwa terdapat pengaruh metode pembelajaran dengan menggunakan pendekatan problem solving terhadap hasil belajar matematika siswa. Hasil yang sama juga ditunjukkan dalam penelitian Astuti (2017) bahwa pembelajaran dengan menggunakan model problem solving terdapat perbedaan yang signifikan terhadap kemampuan berpikir kritis siswa dengan siswa yang memperoleh pembelajaran klasikal. Pada hasil penelitian Hadija (2017) dinyatakan bahwa peningkatan kemampuan pemecahan masalah matematis siswa yang mengikuti pembelajaran matematika dengan model Creatif Problem Solving berbasis kontektual lebih baik daripada siswa yang mengikuti pembelajaran dengan model konvensional pada pokok bahasan segi empat. Sementara itu, hasil penelitian Abduloh (2018) menyatakan bahwa penerapan model pembelajaran Creatif Problem Solving dapat meningkatkan kemampuan pemecahan masalah siswa pada soal literasi matematika.

\section{METODE PENELITIAN}

Penelitian ini merupakan penelitian eksperimen dengan pendekatan kuantitatif. Pada penelitian ini, ada dua kelas sampel penelitian, yaitu kelas eksperimen dengan menggunakan pembelajaran pendekatan problem solving dan kelas kontrol dengan pembelajaran konvensional. Adapun sampel dalam penelitian ini terdiri atas dua kelas dari siswa kelas VII SMP Negeri Simpang Tiga yang dipilih secara purposive sampling.

Desain yang digunakan dalam penelitian ini yaitu pretest-posttest-control group design. Desain penelitian ini dipilih karena penelitian ini menggunakan kelas kontrol dan kelas eksperimen. Tes dilakukan dua kali, yaitu sebelum proses 
Al-Ishlah: Jurnal Pendidikan - ISSN: 2087-949o (p); 2597-940X (e)

Vol. 11, No. 1 (2019)

pembelajaran yang disebut pretest dan sesudah proses pembelajaran yang disebut posttest Yang terlihat seperti berikut.

$\begin{array}{lll}\text { Kelas Eksperimen } & \mathrm{I} & : \mathrm{O} \mathrm{X} \mathrm{O} \\ \text { Kelas Kontrol } & \mathrm{I} & : \mathrm{O}-\mathrm{O} \\ \text { Keterangan: } & \mathrm{I} & \text { : Pemilihan sampel secara acak kelas } \\ & \mathrm{O} & \text { : Pretes dan postes } \\ & \mathrm{X} & \text { : Pembelajaran matematika dengan } \\ & & \text { pendekatan problem solving }\end{array}$

Instrumen dalam penelitian ini hanya menggunakan instrumen tes, yaitu berupa tes uraian untuk mengukur kemampuan pemecahan masalah matematis siswa. Untuk analisis data, peneliti menggunakan bantuan program software SPSS 16,0 dan Microsoft Excel 2007. Sementara, data N-Gain dihitung dengan menggunakan gain ternormalisasi yang dikembangkan oleh Meltzer (2002) sebagai berikut.

Gain ternormalisasi $(\mathrm{g})=\frac{\text { Skor Posttest-Skor Pretest }}{\text { Skor Ideal-Skor Pretest }}$

Tabel 1. Kriteria Skor Gain Ternormalisasi

\begin{tabular}{|c|c|}
\hline Skor Gain & Interpretasi \\
\hline $0,70<\mathrm{g} \leq$ & Tinggi \\
1,00 & \\
\hline $0,30<\mathrm{g} \leq$ & Sedang \\
0,70 & \\
\hline $\mathrm{g} \leq 0,30$ & Rendah \\
\hline
\end{tabular}


Al-Ishlah: Jurnal Pendidikan - ISSN: 2087-949o (p); 2597-940X (e)

Vol. 11, No. 1 (2019)

\section{HASIL PENELITIAN}

Hasil penelitian untuk kemampuan pemecahan masalah siswa secara deskriptif dapat dilihat pada tabel berikut.

Tabel 2. Analisis Statistik Deskriptif N-Gain Kemampuan Pemecahan Masalah

\begin{tabular}{|c|l|r|r|r|c|}
\hline & Kelas & N & Mean & $\begin{array}{c}\text { Std. } \\
\text { Deviation }\end{array}$ & $\begin{array}{c}\text { Std. Error } \\
\text { Mean }\end{array}$ \\
\hline \multirow{2}{*}{ data } & Eksperimen & 21 & .3467 & .15998 & .03491 \\
& Kontrol & 16 & .2250 & .09274 & .02318 \\
\hline
\end{tabular}

\section{Uji Anava Data N-Gain Kemampuan Pemecahan Masalah Matematis}

Berdasarkan hasil pengujian sebelumnya, diketahui bahwa data $\mathrm{N}$-gain kemampuan pemecahan masalah siswa pada kedua kelas berdistribusi normal dan variannya juga sama, sehingga statistik yang digunakan untuk menguji hipotesis penelitian adalah uji anava dua jalur. Analisis ini dilakukan untuk mengetahui pengaruh pembelajaran terhadap dua perlakuan yang berbeda pada kedua kelas yang menjadi sampel penelitian terhadap peningkatan kemampuan pemecahan masalah matematis siswa. Adapun perhitungan anava dua jalur yang dilakukan dengan bantuan SPSS versi 16 pada taraf signifikansi $\alpha=0.05$ dan kriteria pengujian adalah sebagai berikut.

1. Terima $H_{o}$ jika nilai sig. $\geq \alpha$

2. Tolak $H_{o}$ jika niai sig. $\leq \alpha$ (Uyanto, 2009)

Sementara itu, hipotesis penelitiannya adalah sebagai berikut.

Ho : Peningkatan kemampuan pemecahan masalah matematis siswa yang memperoleh pembelajaran dengan pendekatan problem solving lebih baik daripada siswa yang memperoleh pembelajaran konvensional ditinjau secara level siswa

Ha : Peningkatan kemampuan pemecahan masalah matematis siswa yang memperoleh pembelajaran dengan pendekatan problem solving tidak lebih baik daripada siswa yang memperoleh pembelajaran konvensional ditinjau secara level siswa

Berikut disajikan hasil pengujian anava dua jalur untuk data $\mathrm{N}$-gain kemampuan pemecahan masalah. 
Al-Ishlah: Jurnal Pendidikan - ISSN: 2087-949o (p); 2597-940X (e)

Vol. 11, No. 1 (2019)

Tabel 3. Analisis Varian Data N-gain Kemampuan Pemecahan Masalah Matematis

\begin{tabular}{|c|c|c|c|c|c|}
\hline Source & $\begin{array}{c}\text { Type III } \\
\text { Sum of } \\
\text { Squares }\end{array}$ & Df & $\begin{array}{c}\text { Mean } \\
\text { Square }\end{array}$ & F & Sig. \\
\hline Pembelajaran & .031 & 1 & .031 & 6.455 & .016 \\
Level & .443 & 2 & .222 & 45.64 & .000 \\
Pembelajaran* & .003 & 1 & .003 & .535 & .470 \\
Level & .155 & 32 & .005 & & \\
Error & 3.975 & 37 & & & \\
Total & .775 & 36 & & & \\
Corrected Total & & & & & \\
\hline
\end{tabular}

Berdasarkan hasil perhitungan anava dua jalur yang terdapat pada tabel di atas dapat disimpulkan bahwa untuk peningkatan kemampuan pemecahan masalah matematis siswa berdasarkan level siswa, nilai sig. yang diperoleh pada baris level siswa juga kurang dari 0,05, yaitu 0,00 yang berarti Ho ditolak atau dengan kata lain Ha diterima. Artinya, peningkatan kemampuan pemecahan matematis siswa yang memperoleh pembelajaran dengan pendekatan problem solving lebih baik daripada siswa yang memperoleh pembelajaran konvensional jika ditinjau berdasarkan level siswa.

Setelah semua hipotesis yang diajukan teruji, tabel berikut menunjukkan rangkuman hasil pengujian hipotesis penelitian terhadap gain yang berkenaan dengan kemampuan pemecahan masalah matematis siswa pada kedua kelas penelitian dengan taraf signifikansi 0,05 yang dapat dilihat sebagai berikut. 
Al-Ishlah: Jurnal Pendidikan - ISSN: 2087-949o (p); 2597-940X (e)

Vol. 11, No. 1 (2019)

Tabel 4. Rangkuman Pengujian Hipotesis pada Taraf Signifikansi 0,05

\begin{tabular}{|c|c|c|c|c|}
\hline No. & Hipotesis Penelitian & $\begin{array}{l}\text { Jenis Uji } \\
\text { Hipotesis }\end{array}$ & $\begin{array}{c}\text { Pengujian } \\
\text { Ho }\end{array}$ & Hasil \\
\hline & $\begin{array}{c}\text { Peningkatan kemampuan } \\
\text { pemecahan masalah matematis } \\
\text { siswa yang memperoleh } \\
\text { pembelajaran dengan } \\
\text { pendekatan problem solving } \\
\text { lebih baik daripada siswa yang } \\
\text { memperoleh pembelajaran } \\
\text { konvensional ditinjau secara } \\
\text { level siswa }\end{array}$ & $\begin{array}{l}\text { Uji Anava } \\
\text { Dua Jalur }\end{array}$ & Tolak & $\begin{array}{l}\text { Lebih } \\
\text { Baik }\end{array}$ \\
\hline
\end{tabular}

\section{SIMPULAN}

Kemampuan pemecahan masalah yang diuji pada siswa SMPN Simpang Tiga, Pidie, dilihat dari segi level siswa, yaitu siswa yang berkemampuan tinggi, sedang, dan rendahdilakukan untuk melihat kemampuan siswa tersebut secara detail. Hasil yang didapatkan berdasarkan perhitungan anava dua jalur dapat disimpulkan bahwa untuk peningkatan kemampuan pemecahan masalah matematis berdasarkan level siswa terlihat nilai sig. yang diperoleh pada baris level siswa kurang dari 0,05, yaitu 0,00. Ini berarti Ho ditolak atau, dengan kata lain, Ha diterima. Artinya, peningkatan kemampuan pemecahan matematis siswa yang memperoleh pembelajaran dengan pendekatan problem solving lebih baik daripada siswa yang memperoleh pembelajaran konvensional jika ditinjau berdasarkan level siswa. Maka, dapat disimpulkan bahwa peningkatan kemampuan pemecahan masalah matematis siswa yang memperoleh pendekatan problem solving lebih baik daripada siswa yang memperoleh pembelajaran konvensional yang ditinjau dari level siswa.

\section{DAFTAR PUSTAKA}

Astuti. (2017). Pengaruh Pembelajran Problem Solving terhadap kemampuan berpikir kritis siswa kelas XI-IS MA Muhammadyah 2 Paciran. Pdf. Diakses pada tanggal 19 Mei 2017, dari http://jurnalonline.um.ac.id/data/artikel/.pdf. 
Al-Ishlah: Jurnal Pendidikan - ISSN: 2087-949o (p); 2597-940X (e)

Vol. 11, No. 1 (2019)

Abduloh. (2018). Peningkatan Kemampuan Pemecahan Masalah Matematika dalam Soal Literasi Matematika melalui Model Creative Problem Solving Kelas VIII H SMP 9 Semarang. Pdf. Proseding Seminar Nasional Matematika.

Bransford, J.D. dan Stein B.S. (1993). The Ideal Problem Solver: A Guide for Improving Thinking, Learning, and Creativity. Second Edition. New York: W. H. Freeman \& Company.

BSNP. (2006). Standar Isi untuk Satuan Pendidikan Dasar dan Menengah, Standar Kompetensi dan Kompetensi dasar SMP/MTts. Pdf. Jakarta.

Hadija, Herlawan. (2017). Peningkatan Kemampuan Pemecahan Masalah Matematis Siswa Kelas VII Melalui Penerapan Model Pembelajaran Creative Problem Solving berbasis Kontektual. Pdf. Jurnal penelitian pendidikan dan pengajaran matematika vol.3 no.1.

Jacob, C. (2018). Matematika sebagai Pemecahan Masalah. Pdf. Diakses pada tanggal 14 Juli 2018, dari

http://file.upi.edu/Direktori/FPMIPA/JUR._PEND._MATEMATIKA/1945 07161976031 .

Krulik, S.\& Reys, R.E. (1980). Problem Solving in School Mathematics. Reston, Virginia: NCTM.

Meltzer, D. E. (2002). The Relationship between Mathematics Preparation and Conceptual Learning Gain in Physics: A Possible "Hidden Variable" in Diagnostic Pretest Scores: Department of Physics and Astronomy, Iowa State University,Ames, Iowa 50011. Diakses pada tanggal 29 Desember 2012, dari http://www. physicseducation.net/docs/ Addendum_on_normalized_gain. Pdf.

Motter, A. (2010). George Polya, “How To Solve It ?”. Diakses pada tanggal 20 Juni 2012, dari: http://www.math.twsu.edu/history/men/polya.html.

National Council of Teacher of Mathematics. (2000). Principles and Standards for School Mathematics. Reston, VA: NCTM.

Suherman, dkk. (2003). Strategi Pembelajaran Matematika Kontemporer. Bandung: FMIPAUPI. 
Al-Ishlah: Jurnal Pendidikan - ISSN: 2087-949o (p); 2597-940X (e)

Vol. 11, No. 1 (2019)

Sumarmo, Utari. (2012). Pendidikan Karakter serta pengembangan berpikir dan disposisi Matematika dalam Pembelajaran Matematika. Makalah disajikan pada seminar pendidikan Matematika di NTT tanggal 25 Februari 2012.

Turmudi. (2008). Pemecahan Masalah Matematika pdf diakses pada tanggal 4 Juli 2018, dari: http://file.upi.edu/browse.php?dir=Direktori/FPMIPA/JUR._PEND._MAT EMATIKA/196101121987031-TURMUDI/.

Suhendri, H. (2013). Pengaruh Metode Pembelajaran Problem Solving Terhadap Hasil Belajar Matematika Ditinjau dari Kemandirian Belajar. Jurnal Formatif 3(2).

Suherman, dkk. (2003). Evaluasi Pembelajaran Matematika, Bandung: JICA FMIPA UPI.

Sumarmo, Utari. (2012). Pendidikan Karakter serta pengembangan berpikir dan disposisi Matematika dalam Pembelajaran Matematika. Makalah disajikan pada seminar pendidikan Matematika di NTT tanggal 25 Februari 2012.

Turmudi. (2008). Pemecahan Masalah Matematika pdf diakses pada tanggal 4 Juli 2013, dari: http://file.upi.edu/browse.php?dir=Direktori/FPMIPA/JUR._PEND._MAT EMATIKA/196101121987031-TURMUDI/.

Uyanto, S. (2009). Pedoman Analisis Data dengan SPSS. Yogyakarta: Graha Ilmu.

Wardhani, S \& Rumiati, 2011. Instrumen Penilaian dan Hasil Belajar Matematika SMP: Belajar dari PISA dan TIMSS. Jakarta: Pusat Pengembangan dan pemberdayaan Pendidik dan Tenaga Kependidikan. 